\title{
Effects of exposure to cadmium on calcium metabolism: a population study
}

\author{
Jan Staessen, Antoon Amery, Alfred Bernard, Pierre Bruaux, Jean-Pierre Buchet, \\ Françoise Claeys, Pierre De Plaen, Geneviève Ducoffre, Robert Fagard, Robert R Lauwerys, \\ Paul Lijnen, Laurence Nick, Annie Saint Remy, Harry Roels, Désire Rondia, Francis Sartor, \\ Lutgarde Thijs
}

\begin{abstract}
The objective was to investigate the hypothesis that environmental exposure to cadmium may affect calcium metabolism in the population at large. The 1987 participants $(965$ men and 1022 women), from 20 to 80 years old, constituted a random sample of the population of four Belgian districts. The urinary excretion of cadmium, a measure of lifetime exposure, averaged $9.3 \mathrm{nmol} / 24 \mathrm{~h}$ in men (range 0.4-324 nmol/24 h) and $7 \cdot 1 \mathrm{nmol} / 24 \mathrm{~h}$ (range $0 \cdot 1-71$ nmol/24 h) in women. Serum alkaline phosphatase activity and the urinary excretion of calcium correlated significantly and positively with urinary cadmium excretion in both men and women, and serum total calcium concentration negatively with urinary cadmium excretion in men only. The regression coefficients obtained after adjustment for significant covariates indicated that when urinary cadmium excretion increased twofold, serum alkaline phosphatase activity and urinary calcium excretion rose by $3-4 \%$ and 0.25 $\mathrm{mmol} / 24 \mathrm{~h}$ respectively, whereas in men serum total calcium concentration fell by $6 \mu \mathrm{mol} / 1$. After adjustment for significant covariates the relation between serum total calcium concentration and urinary cadmium excretion was
\end{abstract}

Hypertension and Cardiovascular Rehabilitation Unit, Department of Pathophysiology, University of Leuven, Leuven, Belgium

J Staessen, A Amery, R Fagard, P Lijnen, L Thijs

Environmental Toxicology Unit, University of Liège, Liège, Belgium

A Saint Remy, D Rondia, F Sartor

Industrial Toxicology and Occupational Medicine

Unit, University of Louvain, Brussels, Belgium

A Bernard, J-P Buchet, R R Lauwerys, H Roels

Institute of Hygiene and Epidemiology, Ministry of Health and Social Affairs, Brussels, Belgium

P Bruaux (died 8 July 1989), F Claeys, P De Plaen, G Ducoffre, L Nick not significant in women. The findings suggest that even at environmental exposure levels calcium metabolism is gradually affected, as cadmium accumulates in the body. The morbidity associated with this phenomenon in industrialised countries remains presently unknown and requires further investigation.

The exposure of human populations to cadmium via the environment is raising much concern, as cadmium is a heavy metal with high toxicity and accumulates in the body. ${ }^{1}$

Cadmium interferes with the metabolism of vitamin $\mathrm{D}$, calcium, and collagen, and its accumulation may lead to osteomalacia and osteoporosis. ${ }^{12}$ These effects are usually considered to be late manifestations of severe cadmium poisoning, and have been seen in exposed workers and in malnourished subjects. ${ }^{1-4}$ The quantitative dose-response relation for the effects of cadmium on calcium and bone metabolism, however, remains presently unknown. The present report, part of a cross sectional study on the effects of cadmium on public health, ${ }^{5-7}$ investigated whether environmental exposure to cadmium influences calcium metabolism in the population at large.

\section{Methods}

SUBJECTS

As described elsewhere, ${ }^{5-7}$ the 2327 subjects (age range from 20 to 79 ) constituted a random sample of the population of four Belgian districts selected to provide a wide range of environmental exposure to cadmium. Subjects were excluded from the present analysis when not all relevant measurements were available $(n=248)$, when 24 hour urine samples were judged under or over collected by previously published criteria $(n=44),{ }^{8}$ or when either occupational exposure to heavy metals $(n=41)$ or smoking habits $(n=7)$ could not be ascertained from a self administered questionnaire. 


\section{FIELD WORK}

All participants were visited at home on several occasions. Body weight was determined with indoor clothing. A self administered questionnaire was used to inquire about the subjects' medical history, their current and past occupations, smoking habits, alcohol consumption, intake of medicines, and about the menstrual state of female participants. The subjects collected a 24 hour urine sample in a wide neck metal free polyethylene container. At a separate home visit, usually within two weeks of the urine collection, $20 \mathrm{ml}$ of venous blood were drawn.

\section{BIOCHEMICAL MEASUREMENTS}

The biochemical techniques and procedures for quality control have been described in detail elsewhere. ${ }^{5}$ Alkaline phosphatase activity was determined on a COBAS-BIO centrifugal analyser (Roche Diagnostics). ${ }^{9}$ Serum and urinary calcium concentrations were measured by compleximetry, ${ }^{10}$ and urinary cadmium by electrothermal atomic absorption spectrometry using a stabilised temperature platform furnace and Zeeman background correction. ${ }^{5}$

\section{STATISTICAL ANALYSIS}

For statistical analysis the SAS software package was used. ${ }^{11}$ Where appropriate a logarithmic transformation was applied to normalise the distribution of the biochemical measurements. Statistical methods included Student's $t$ test, analysis of covariance, and single and multiple linear regression.

Significant covariates were traced by stepwise regression. Age adjustments included both a linear and quadratic term of age.

\section{Results}

CHARACTERISTICS OF THE PARTICIPANTS

The present analysis included 965 men and 1022 women. Table 1 summarises their anthropometric characteristics and biochemical results.

Current smoking was reported by 471 men (median tobacco consumption equivalent to 18 cigarettes a day), and 354 women (median 20 cigarettes a day), and regular alcohol intake by 357 men (median alcohol consumption $20 \mathrm{~g} /$ day) and 142 women (median $16 \mathrm{~g} /$ day). Fifty two men and 122 women were on treatment with diuretics and 210 women took the contraceptive pill. The study population included 462 postmenopausal women.

\section{SERUM ALKALINE PHOSPHATASE ACTIVITY}

Serum alkaline phosphatase activity (SAPA) was positively associated with urinary cadmium excretion (UCd) in both sexes (figure). The single correlation coefficient was $0 \cdot 10(\mathrm{p}=0.003)$ in men and 0.30 $(p<0.001)$ in women.

Age and body mass index combined explained 3\% $(p<0.001)$ of the variance of SAPA in men, and $21 \%(\mathrm{p}<0.001)$ in women (table 2$)$. The SAPA was independently related to $\gamma$-glutamyltranspeptidase activity, to being a regular consumer of alcoholic beverages, and to the daily alcohol consumption (g/day) (table 2). These three covariates combined explained $5 \%(p<0.001)$ of the variance of SAPA in men, and $8 \%$ of the variance $(p<0.001)$ in women.

After adjustment for significant covariates SAPA remained positively associated with $U C d$ in men (partial $\mathbf{R}^{2}=0.017 ; \mathrm{p}<0.001$ ) and women (partial $\left.R^{2}=0.004 ; p=0.02\right)$. The slopes of these relations (table 2) indicated that a twofold increase in UCd was accompanied by a rise in SAPA by around 3-4\% (95\% confidence interval from 2 to $6 \%$ in men, and from 1 to $5 \%$ in women).

\section{SERUM TOTAL CALCIUM CONCENTRATION}

Serum total calcium concentration (STCa) was negatively associated with UCd in men (figure); the

Table 1 Characteristics of the participants

\begin{tabular}{|c|c|c|}
\hline & $\operatorname{Men}(n=965)$ & Women $(n=1022)$ \\
\hline $\begin{array}{l}\text { Clinical measurements: } \\
\text { Age }(\mathrm{y}) \\
\text { Body mass index }\left(\mathrm{kg} / \mathrm{m}^{2}\right)\end{array}$ & $\begin{array}{l}48.4(15.9) \\
25.5(3.6)\end{array}$ & $\begin{array}{l}47 \cdot 6(16 \cdot 4) \\
25 \cdot 3(5 \cdot 1)\end{array}$ \\
\hline $\begin{array}{l}\text { Serum measurements: } \\
\text { Alkaline phosphatase }(\mathrm{U} / \mathrm{l}) \dagger \\
\gamma-\mathrm{GT}(\mathrm{U} / \mathrm{l}) \dagger \\
\text { Total calcium (mmol/l) } \\
\text { Magnesium }(\mathrm{mmol} / \mathrm{l})\end{array}$ & $\begin{array}{c}120(33-857) \\
14(2-252) \\
2 \cdot 37(0 \cdot 10) \\
1 \cdot 01(0 \cdot 07)\end{array}$ & $\begin{array}{c}109(22-527)^{\star \star \star} \\
10(2-335)^{\star \star \star} \\
2.36(0.11) \\
1.00(0.08)\end{array}$ \\
\hline $\begin{array}{l}\text { Urinary measurements: } \\
\text { Volume }(1 / 24 \mathrm{~h}) \\
\text { Cadmium }(\mathrm{nmol} / 24 \mathrm{~h}) \dagger \\
\text { Calcium }(\mathrm{mmol} / 24 \mathrm{~h}) \\
\text { Creatinine }(\mathrm{mmol} / 24 \mathrm{~h})\end{array}$ & $\begin{array}{l}1.65(0.70) \\
9.3(0.4-324) \\
4.86(2 \cdot 68) \\
15.4(4 \cdot 0)\end{array}$ & $\begin{array}{l}1.67(0 \cdot 74) \\
7 \cdot 1(0 \cdot 1-70 \cdot 8)^{\star \star \star} \\
3.95(2 \cdot 20)^{\star \star \star} \\
10 \cdot 5(2 \cdot 7)^{\star \star \star}\end{array}$ \\
\hline
\end{tabular}

Values are means (SD). For logarithmically transformed distributions $(\dagger)$ the geometric mean and range are presented. $\star \star \star p<0.001$ for difference between men and women. 

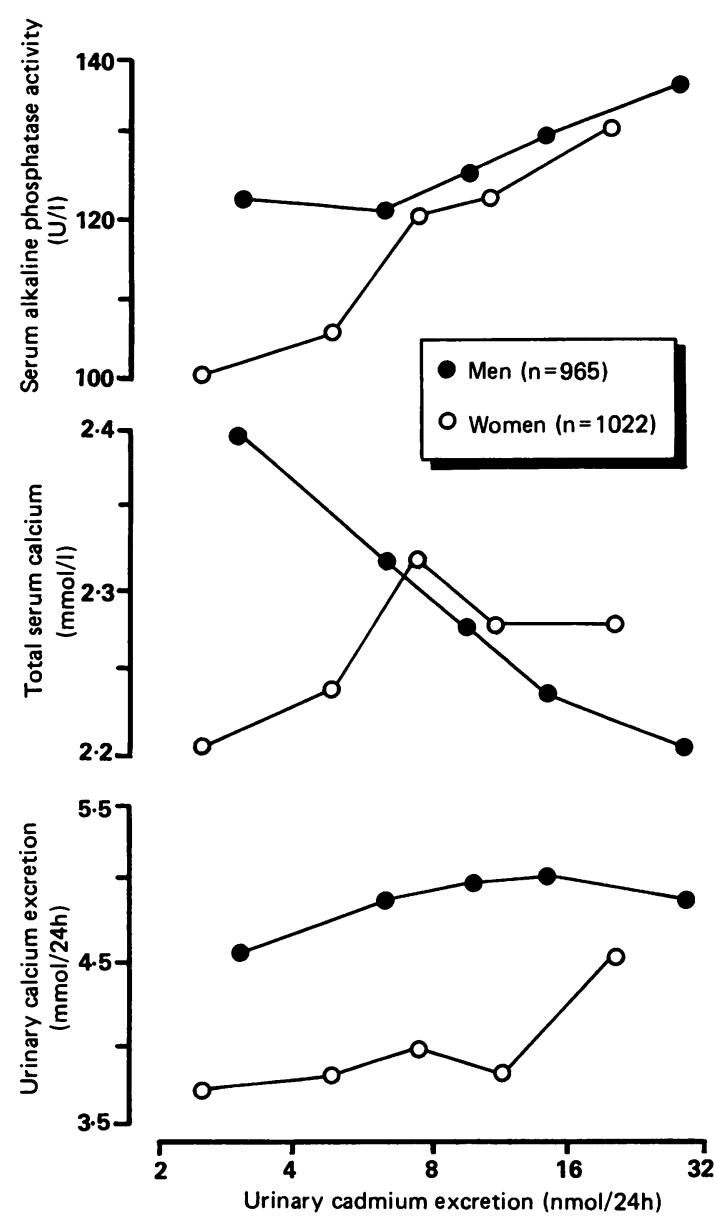

Serum alkaline phosphatase activity (top panel), serum total calcium concentration (middle panel), and urinary excretion of calcium (bottom panel) in quintiles of the body burden of cadmium (estimated from the urinary excretion of cadmium). The analyses were performed in men and women separately.

correlation coefficient was $-0.17(p<0.001)$. The single correlation coefficient between STCa and UCd in women was positive $(r=0.06 ; p=0.05)$.

After adjustment for significant covariates (table 2), an independent and negative correlation was found between STCa and UCd in men (partial $\mathbf{R}^{2}=0.01$; $\mathrm{p}<0.001$ ). The slope of this relation (table 2) indicated that a twofold rise in UCd was associated with a decrease in STCa of $6 \mu \mathrm{mol} / 1$ (95\% confidence interval from 3 to $12 \mu \mathrm{mol} / \mathrm{l})$. In women the partial correlation between STCa and UCd $(r=0.004)$, when adjusted for significant covariates, was far from significant.

\section{CALCIURIA}

Urinary calcium excretion (UCa) tended to be positively associated with UCd in both sexes (figure).
The single correlation coefficient was $0.05(\mathrm{p}=0 \cdot 1)$ in men and $0 \cdot 10(p=0.001)$ in women.

After adjustment for significant covariates (table 2), an independent and positive correlation was found between UCa and UCd in the two sexes (partial $R^{2}=0.01 ; p<0.001$ in both men and women). The slopes of these relations (table 2) indicated that a twofold rise in UCd was associated with an increase in UCa by approximately $0.25 \mathrm{mmol} / 24 \mathrm{~h}(95 \%$ confidence interval from 0.13 to $0.45 \mathrm{mmol} / 24 \mathrm{~h}$ in men, and from 0.10 to $0.39 \mathrm{mmol} / 24 \mathrm{~h}$ in women).

\section{EXPOSURE AT WORK}

Possible exposure to heavy metals at work was reported by $304 \mathrm{men}$; UCd in these subjects averaged $13.7 \mathrm{nmol} / 24 \mathrm{~h}$ (range: $0.7-324 \mathrm{nmol} / 24 \mathrm{~h}$ ) and was higher $(\mathrm{p}<0.001)$ than in the other men (mean: $7.9 \mathrm{nmol} / 24 \mathrm{~h}$; range: $0.4-34 \mathrm{nmol} / 24 \mathrm{~h}$ ). Excluding men with exposure to cadmium at work, however, did not materially alter the size of the partial regression coefficients for UCd shown in table 2. For the relation with SAPA the partial regression coefficient was $0.048 \pm 0.018 \log \mathrm{U} / \mathrm{l} / \log \mathrm{nmol} / 24 \mathrm{~h}$ $(\mathrm{p}=0.01)$; for STCa $-0.011 \pm 0.015 \mathrm{mmol} / \mathrm{log}$ $\mathrm{nmol} / 24 \mathrm{~h}$; and for UCa $1.313 \pm 0.358 \mathrm{mmol} / \mathrm{nmol}$ $(\mathbf{p}=0.003)$.

\section{Discussion}

In the present population study, three indices of calcium metabolism were related to the urinary excretion of cadmium, a reliable index of lifetime exposure to cadmium. ${ }^{1}$ The direction of the correlations was positive for SAPA and for UCa in both sexes, and negative for STCa in men.

Liver and bone isoenzymes constitute the principal fractions of alkaline phosphatase activity in the serum of normal adults. ${ }^{1213}$ Serum alkaline phosphatase activity increases with age, mainly due to an increased release of the enzyme from the hepatocytes beyond age $50 . .^{1314-16}$ When SAPA phosphatase is high, normal serum $\gamma$-glutamyltranspeptidase activity suggests an involvement of bone tissue. In the present analysis the effects of ageing and liver dysfunction on alkaline phosphatase activity were accounted for. Adjustments for liver dysfunction were effected based on serum $\gamma$-glutamyltranspeptidase activity, reported alcohol intake, and the amount of alcohol consumed each day (g/day).

Serum total calcium concentration and the UCa decrease with advancing age. ${ }^{17}$ Diuretics increase STCa, lower calciuria, and improve calcium balance. ${ }^{18-21}$ Sex steroids, including oral contraceptives, stimulate bone formation and decrease $\mathrm{SCa}$ and $\mathrm{UCa}$, whereas withdrawal of sex hormones after the menopause leads to opposite effects. ${ }^{22-24}$ The effects of age, diuretics, the contraceptive pill, and menopause on STCa and calciuria were confirmed in the present 
Table 2 Multiple regression analysis

\begin{tabular}{|c|c|c|c|c|c|c|}
\hline & \multicolumn{3}{|l|}{ Men } & \multicolumn{3}{|l|}{ Women } \\
\hline & $S A P A$ & $S T C a$ & $U C a$ & $S A P A$ & $S T C a$ & $U C a$ \\
\hline \multirow[t]{2}{*}{$\begin{array}{l}\mathrm{R}^{2} \\
\text { Intercept }\end{array}$} & $\begin{array}{l}0.067 \\
2 \cdot 164\end{array}$ & $\begin{array}{l}0.099 \\
2.411\end{array}$ & $\begin{array}{r}0.142 \\
-3.296\end{array}$ & $\begin{array}{l}0.284 \\
1.756\end{array}$ & $\begin{array}{l}0.045 \\
2 \cdot 363\end{array}$ & $\begin{array}{r}0.095 \\
-3.168\end{array}$ \\
\hline & \multicolumn{6}{|c|}{ Regression coefficients } \\
\hline 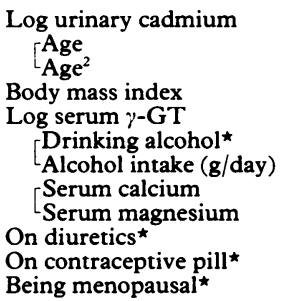 & $\begin{array}{l}0.056 \\
-78 \mathrm{E}-4 \\
78 \mathrm{E}-8 \\
24 \mathrm{E}-4 \\
0.094 \\
-0.013 \\
-48 \mathrm{E}-5 \\
= \\
\text { NS } \\
=\end{array}$ & $\begin{array}{l}-0.021 \\
-19 \mathrm{E}-4 \\
94 \mathrm{E}-8 \\
27 \mathrm{E}-4 \\
= \\
= \\
- \\
= \\
-\end{array}$ & $\begin{array}{l}0.972 \\
0.077 \\
-13 \mathrm{E}-4 \\
0.113 \\
- \\
- \\
- \\
\quad 0.402 \\
2.934 \\
-1.402 \\
-\end{array}$ & $\begin{array}{l}0 \cdot 035 \\
-13 \mathrm{E}-4 \\
40 \mathrm{E}-6 \\
29 \mathrm{E}-4 \\
0 \cdot 145 \\
-0 \cdot 029 \\
-36 \mathrm{E}-5 \\
- \\
\text { NS } \\
\text { NS } \\
\text { NS }\end{array}$ & $\begin{array}{l}\text { NS } \\
\quad 61 \mathrm{E}-5 \\
-17 \mathrm{E}-6 \\
\mathrm{NS} \\
= \\
= \\
= \\
- \\
0.037 \\
-0.031 \\
0.046\end{array}$ & $\begin{array}{l}\quad 0.840 \\
0.076 \\
-98 \mathrm{E}-5 \\
\mathrm{NS} \\
- \\
- \\
- \\
\\
1.697 \\
1.438 \\
-1.052 \\
-0.321 \\
\text { NS }\end{array}$ \\
\hline
\end{tabular}

Only significant regression coefficients are presented (exponent of base 10 given, where appropriate); NS = non-significant; $-=$ not considered for entry into the model. Bracketed covariates were tested simultaneously for entry into the model.

$\mathrm{SAPA}=$ Serum alkaline phosphatase activity (logarithmically transformed); STCa = serum total calcium concentration; UCa $=$ urinary calcium excretion; GT $=\gamma$-glutamyltranspeptidase activity.

$\star$ Coded 0 or 1 for condition being present or absent.

population; they were taken into account when the relations between STCa and UCa and the body burden of cadmium were investigated (table 2). Acute hypermagnesaemia probably inhibits the secretion of parathyroid hormone ${ }^{25}$ and magnesium ions compete with calcium for reabsorption in the loop of Henle. ${ }^{26}$ These mechanisms ${ }^{25} 26$ may explain why, in our study, a positive relation was found between serum magnesium concentration and $\mathrm{UCa}$ (table 2).

Interference with the metabolism of calcium is usually considered to be a late manifestation of severe cadmium intoxication. By contrast with this long held belief, the associations shown in the figure and the fit obtained with linear regression (table 2 ) suggest that no threshold exists, and that the effects on calcium metabolism develop gradually, as during life cadmium accumulates in the body. Indeed, the slopes of the independent relations reported in table 2 show that when UCd doubles SAPA and UCa rise in both sexes by $3-4 \%$ and $0.25 \mathrm{mmol} / 24 \mathrm{~h}$ respectively, whereas SCa in men falls by $6 \mu \mathrm{mol} / 1$. These effects on calcium metabolism may be due to renal tubular dysfunction, or the development of vitamin $D$ resistance, or both. ${ }^{12}$

Whether the small metabolic effects seen in the present study also lead to clinically manifest morbidity in the population at large remains to be elucidated. Among the Shipham residents ${ }^{27}$ and among British workers ${ }^{28}$ exposure to cadmium was not associated with excess mortality from fractures. On the other hand, bone lesions have been experimentally induced by cadmium in several species of laboratory animals, in whom the combined effects of cadmium, poor nutrition, and low vitamin D intake proved to be particularly harmful. ${ }^{2}$ The results from these animal studies are supported by epidemiological findings. Indeed, about 50 cases of osteomalacia or osteoporosis have been seen among cadmium exposed labourers world wide, ${ }^{2}$ and some 150 Japanese subjects have developed bone lesions as a consequence of severe exposure to cadmium via the environment. ${ }^{2}$ The incidence of these bone effects appears to have peaked 30 to 40 years ago when dietary intake of nutrients was often deficient in countries with reported cases. In developed countries and in modern times, however, many subjects suffer from decalcification of the skeleton as a result of ageing, or hormonal or nutritional deficiencies, or both. ${ }^{17}$ It is therefore conceivable that in these subjects, who are at higher risk of skeletal deformation, environmental exposure to cadmium through its effect on calcium metabolism may precipitate overt bone disease and contribute to osteoporosis and its consequences-for example, lower forearm fractures, compression fractures of the vertebrae, and hip fractures. As the UCas found in our present study were comparable with those of other industrialised countries, ${ }^{29}{ }^{30}$ this hypothesis is an important public health issue and requires further investigation.

The Cadmibel Study was financially supported by the Ministry of Health and Social Affairs, the Ministry of the Flemish Community, the Ministry of the Brussels Region, the Belgian National Fund for Medical Research, and the International Lead and Zinc Organisation. The authors gratefully acknowledge the comments of Prof J Dequeker and Dr P Geussens, University of Leuven, Belgium; the continuous support of Dr G Vyncke, Provinciale Gezondheidsinspectie Limburg, Hasselt, Belgium; and the collaboration of the general practitioners of the 
districts involved in the study. Expert technical and secretarial assistance was provided by $\mathrm{M}-\mathrm{J}$ Jehoul, $\mathrm{V}$ Marien, O Palmans, Y Toremans, and S Van Hulle.

\section{Appendix}

\section{CONVERSION OF UNITS}

$\begin{array}{ll}\text { Cadmium: } & 1 \mathrm{nmol}=112.4 \mathrm{ng} \\ \text { Calcium: } & 1 \mathrm{mmol}=40 \cdot 1 \mathrm{mg} \\ \text { Creatinine: } & 1 \mathrm{mmol}=113.1 \mathrm{mg} \\ \text { Lead: } & 1 \mu \mathrm{mol}=207 \cdot 1 \mu \mathrm{g} \\ \text { Magnesium: } & 1 \mathrm{mmol}=24.3 \mathrm{mg}\end{array}$

Requests for reprints to: Jan Staessen $\mathrm{MD} \mathrm{PhD}$, Inwendige Geneeskunde, UZ Gasthuisberg, Herestraat 49, B-3000 Leuven, Belgium.

1 Bernard A, Lauwerys R. Cadmium in human population. Experientia 1984;40:143-50.

2 Kjellström T. Chapter 10: Effects on bone, on vitamine D, and calcium metabolism. In: Friberg L, Elinder CG, Kjellström T, Nordberg GF, eds. Cadmium and Health. A toxicological and epidemiological appraisal. Volume II. Effects and Response. Boca Raton, Florida: CRC Press, 1985:111-58.

3 Kazantzis G, Flynn FV, Spowage JS, Trott DG. Renal tubular malfunction and pulmonary emphysema in cadmium pigment workers. Quat J Med 1963;32:165-92.

4 Kazantzis G. Renal tubular dysfunction and abnormalities of calcium metabolism in cadmium workers. Environ Health Perspect 1979;289:155-9.

5 Lauwerys R, Amery A, Bernard A, et al. Health effects of environmental exposure to cadmium. Objectives, design and organization of the Cadmibel Study: a cross-sectional morbidity study carried out in Belgium from 1985 to 1989. Environ Health Perspect 1990;87:283-9.

6 Staessen J, Amery A, Bernard A, et al. Blood pressure, the prevalence of cardiovascular diseases and exposure to cadmium: a population study. Am J Epidemiol 1991 (in press)

7 Buchet JP, Lauwerys R, Roels $\mathrm{H}$, et al. The cadmium burden of the general population may lead to renal effects. Lancet 1990;336:699-702

8 Staessen J, Bulpitt CJ, Fagard R, Joossens JV, Lijnen P, Amery A. Salt intake and blood pressure in the general population: a controlled interyention trial in two towns. J Hypertens 1988;6:965-73.

9 Empfehlungen der Deutsche Gesellsschaft für Klinische Chemie: Standardisierung von Methoden zur Bestimmung von Enzymaktivitäten in biologischen Flüssigkeiten. Zeitschrift fur Klinische Chemie und Klinische Biochemie 1972;10 1892-192.
10 Schmid RW, Reilley CN. New complexon for titration of calcium in the presence of magnesium. Anal Chem 1957;29:264-8.

$11 S A S / S T A T$ guide for personal computers, version 6th ed. Cary, North Carolina: The SAS Institute Inc, 1987.

12 Statland BE, Nishi H, Young DS. Serum alkaline phosphatase: total activity and isoenzyme determinations made by use of the centrifugal fast analyser. Clin Chem 1972;18:1468-74

13 Whitaker KB, Whitby LG, Moss DW. Activities of bone and liver alkaline phosphatases in serum and disease. Clin Chim Acta 1977;80:209-20.

14 Sharland DE. Alkaline phosphatase: the isoenzyme pattern in the elderly and changes in total serum levels with age. Clin Chim Acta 1974;56:187-98.

15 Fenuku RIA, Foli AK. Variations in total serum alkaline phosphatase activity with age and sex in adult and adolescent Ghanaians. Clin Chim Acta 1975;60:303-6.

16 Hitz J, Daigle G, Petitclerc C, Schielle F, Siest G. Automated quantification of bone and liver alkaline phosphatase isoenzymes of human serum. Clin Chim Acta 1980;107:203-10.

7 Dequeker J. Bone and ageing. Ann Rheum Dis 1975;34:100-15.

18 Lamberg B-A, Kuhlbäck B. Effect of chlorothiazide and hydrochlorothiazide on the excretion of calcium in urine. Scand $J$ Clin Lab Invest 1959;11:351-7.

19 Middler S, Pak CY, Murad F, Bartter FC. Thiazide diuretics and calcium metabolism. Metabolism 1973;22:139-46.

20 Ljunghall S, Backman U, Danielson BG, Fellstrom B, Johansson G, Wikstrom B. Calcium and magnesium metabolism during long-term treatment with thiazides. Scand J Uro Nephrol 1981;15:257-62.

21 Stote RM, Smith LH, Wilson DM, Dube WJ, Goldsmith RS Arnaud CD. Hydrochlorothiazide effects on serum calcium and immunoreactive parathyroid hormone concentrations: studies in normal subjects. Ann Intern Med 1972;77:587-91.

22 Riggs BL, Melton III LJ. Involutional osteoporosis. $N$ Engl J Med 1986;314:1676-86.

23 Raisz LG. Local and systemic factors in the pathogenesis of osteoporosis. N Engl J Med 1988;318:818-28.

24 Nordin BEC, Heaney RP. Calcium supplementation of the diet: justified by present evidence. $B M J 1990 ; 300: 1056-60$

25 Cholst IN, Steinberg SF, Tropper PJ, Fox HE, Segre GV, Bilezikian JP. The influence of hypermagnesemia on serum calcium and parathyroid hormone levels in human subjects. $N$ Engl J Med 1984;310:1221-5.

26 Carney SL, Wong NLM, Quamme GA, Dirks JH. Effect of magnesium deficiency on renal magnesium and calcium transport in the rat. $J$ Clin Invest 1980;65:180-8.

27 Inskip $H$, Beral V, McDonall M. Mortality of Shipham residents: 40 year follow-up. Lancet 1982;i:896-9.

28 Armstrong BG, Kazantzis G. The mortality of cadmium workers. Lancet 1983;i:1425-7.

29 Staessen J, Bulpitt CJ, Roels H, et al. Urinary cadmium and lead concentrations and their relation to blood pressure in a population with low exposure. Br J Ind Med 1984;41:241-8.

30 Elinder CG. Chapter 5: Cadmium: uses, occurrence and intake. In: Friberg L, Elinder CG, Kjellström T, Nordberg GF, eds. Cadmium and health. A toxicological and epidemiological appraisal. Volume I. Exposure, dose, and metabolism. Boca Raton, Florida: CRC Press, 1985:23-79.

Accepted 18 February 1991 